DOI: $10.14451 / 1.171 .102$

\title{
К ВОПРОСУ О ФИНАНСИРОВАНИИ ПРОГРАММ РАЗВИТИЯ КУРОРТА КАВКАЗСКИХ МИНЕРАЛЬНЫХ ВОД
}

\author{
(C) 2019 Хурмагов Ибрагим Алиевич \\ кандидат экономических наук, доцент кафедры экономики и антимонопольного регулирования \\ Российская академия народного хозяйства и государственной службы \\ при Президенте Российской Федерации, Северо-Кавказский институт-филиал \\ г. Пятигорск, ул. Дунаевского, 5 \\ Email: Ibragim-kn@mail.ru
}

В статье рассматриваются основные направления, способы и средства достижения стратегических целей устойчивого развития и обеспечения национальной безопасности Российской Федерации на территории Северо-Кавказского федерального округа до 2025 года.

Ключевые слова: курорт, природные ресурсы, экология, стратегия, программы, финансы, инвестиции, бюджет, контроль.

В связи с ухудшением экологической ситуации на территории курортного субрегиона Ставропольского края - Кавказских Минеральных Вод (КМВ), актуализируется вопрос о защите ресурсного обеспечения санаторно-курортного комплекса. А ведь по объему природного потенциала и наличию функционирующей курортно-рекреационной базы он является уникальной здравницей России, обеспечивающей, как туристско-оздоровительный отдых, так и лечение граждан с весьма широким спектром заболеваний.

Однако в результате научного исследования выявлены серьезные проблемы, среди которых: существенный экологический дисбаланс, требующий немедленного восстановления. Если пренебречь проблемой, то старинный, популярный курорт может лишиться лечебного грязевого источника - озера Тамбукан. При неправильном его использовании, загрязнении минеральными удобрениями и ядохимикатами близлежащими сельхозпредприятиями, водоем опресняется и грязь теряет свои целебные свойства.

Далее, ежегодно уменьшается объем поступающих минеральных источников. Более того, их качество ставится под сомнение, поскольку на территории курорта находятся вредные производства, загрязняющие окружающую среду.

Также следует отметить значительный физический и моральный износ основных производственных фондов санаторно-курортного комплекса; ветхость жилого фонда, возраст которого более ста лет, что создает непривлекательный вид в курортной зоне; низкий уровень культуры обслуживания в сравнении с популярными зару-

бежными курортами; озабоченность вызывает и неудовлетворительная дорожно-транспортная инфраструктура курорта. То есть, значительную долю антропогенных нагрузок, влияющих на изменение окружающей природной среды, осуществляют непостоянные очаги загрязнения, а переменные - тот же транспортный комплекс, хотя это не учитывается в экономическом механизме регулирования сферы природопользования КМВ.

В арсенале мер по более эффективному социально-экономическому и экологическому управлению курортом, конечно же, главным является финансирование. Следует вспомнить, что Распоряжением Правительства РФ от 06.09.2010 г. была утверждена «Стратегия социально-экономического развития Северо-Кавказского федерального округа до 2025 года» (далее - Стратегия), в соответствии с которой, финансирование госпрограмм, в том числе региона КМВ, будет производиться не только за счет средств отраслевых федеральных министерств и ведомств, но и из федерального бюджета. В проекте государственной программы по развитию Северного Кавказа до 2025 г. Минрегионразвития России были определены инвестиционные вложения 3,89 трлн. руб., из которых более 2,604трлн. руб. намечалось выделить из федерального бюджета и 195,2 млрд.- из бюджетов субъектов федерации, входящих в СКФО. Кроме того, из внебюджетных источников было заложено в программу 1096,9 млрд. руб. Для Ставропольского края запланировано - 69,9 млрд. руб., в том числе 63,2 млрд. руб.- из федерального бюджета. На развитие курорта КМВ - 213,9 млрд. руб., доля 
федерального бюджета должна составить 52,0 млрд. руб. [1].

Стратегия поставила цель - обеспечить условия для опережающего развития реального сектора экономики в субъектах Российской Федерации, входящих в состав Северо-Кавказского федерального округа, создания новых рабочих мест, повышение уровня жизни населения.

Какими же параметрами характеризуется оптимальный сценарий, предполагающий полную реализацию заявленных в Стратегии целей и мероприятий? Что должна дать реализация Стратегии региону?

Прежде всего, КМВ должны быть ведущим лечебно-оздоровительным центром в рекреации, а в масштабах Северо-Кавказского федерального округа - еще и центром горнолыжного туризма в России.

Учитывая необходимость здорового питания курортников, субрегион станет крупнейшим поставщиком экологически чистых продуктов питания. Те, кто хоть раз побывал на территории Кавказских Минеральных Вод или в горах близлежащих республиках, входящих в округ, тот думает о привлекательности территории для постоянного проживания.

И еще планировалось, что регион станет развитым транспортным узлом, связывающим Россию со странами Средиземноморья и Закавказья.

Таким образом, упор делается на динамичное развитие санаторно-курортного и туристского комплекса; глубокую модернизацию социальной инфраструктуры, в том числе: образования, здравоохранения, жилого сектора, обеспечивающие значительное повышение качества жизни населения; значительное улучшение инвестиционного климата, включая иностранных инвесторов; опережающее развитие транспортной отрасли субрегиона, отвечающей потребностям экономики и населения и др.

Одновременно будут обеспечены новые рабочие места и повышение уровня занятости в округе.

Поддержку инвестиционных проектов по развитию санаторно-курортной и туристской инфраструктуры в СКФО, как следует из Стратегии, будут осуществлять путем реализации государственных целевых программ через ОАО «Особые экономические зоны» и Инвестиционный фонд РФ. А в отборе первостепенных проектов и софинансировании мероприятий по разработке проектно-сметной документации и строительства планировалось задействовать Институт развития Северного Кавказа. Следующий шаг по активному развитию курорта доверялся сразу нескольким крупным структурам: OAO «Курорты Северного Кавказа» (финансируют Сбербанк, Банк развития ОАО «Особые экономические зоны») и Корпорация по развитию Северного Кавказа (ВЭБ).

Однако в ходе исследования было выявлено, что данный документ так и остался проектом. В нем изначально не были указаны способы антикризисного экономического управления, например, отсутствуют планы демографической политики в округе - при росте рождаемости в некоторых республиках наблюдается увеличение числа безработных.

Планировалось создать Агентство по трудовой миграции при дефиците вакансий и росте безработицы, деятельность которого состояла бы в переселении безработных лиц в другие регионы России, под конкретные вакансии крупных производителей. Одновременно в регион привлекались бы специалисты из других регионов.

Основательных изменений в развитии СКФ, в том числе курорта КМВ, пока не произошло. Опираясь на различные информационные источники, в том числе материалы Счетной палаты, имеют место случаи, когда средства федерального бюджета, направляемые в регион, не доходят до него.

По нашему мнению, здесь необходим механизм жесткого финансового контроля за их получением и расходованием, предполагающий также адекватную персональную ответственность. Но ситуация годами не меняется, при этом, имеет место безнаказанное нецелевое использование средств, выделяемых в регион.

Таким образом, финансовые и социально-экономические меры по перестройке развития рекреационного региона должны обеспечиваться мерами политического, правового и иного характера.

С переходом к рыночной экономике основным регулятором ее функционирования и развития, наряду с государством, является рыночный механизм. Но в сфере природопользования в регионах России он развит недостаточно.

Считаем, нельзя рассчитывать только на бюджетные средства, не используя другие, негосударственные, источники самофинансирования, к примеру, тот же курортный сбор, который 
введен пока как эксперимент и будет направлен строго на обеспечение природоохранной деятельности рекреационной территории, в первую очередь, на создание обособленных экологических фондов предприятий в виде специального счета в местном отделении частного банка, обслуживающего предприятие. Также источниками создания экологических фондов предприятий могут быть амортизационные отчисления по природоохранным объектам и сооружениям; штрафы за загрязнение окружающей среды в пределах норм; штрафные платежи за превышение норм загрязнения; а также рентные платежи. Еще сюда можно отнести возможные целевые субсидии и кредиты на осуществление природоохранных мероприятий, получаемые на конкурсной основе (гранты) из бюджетных средств; кредиты государственных и коммерческих банков; прибыль предприятий, включая экономию по уплате налога на прибыль при ее использовании на обеспечение природоохранных нужд.

А вот основными направлениями расходования средств экологических фондов предприятия, на наш взгляд, должны быть различные природоохранные мероприятия, компенсационные расчеты с другими предприятиями, юридическими лицами и гражданами в случае приобретения дополнительных квот на загрязнение и прямой компенсации нанесенного ущерба.

Считаем, чтобы сформировать устойчивый механизм системы финансирования охраны природы курортного региона, необходимо сначала образовать финансово-кредитный механизм управления природопользованием, который должен включать систему финансирования экологических программ и различных акций по охране окружающей среды из бюджетов различных уровней, различных экологических фондов (инновационных и экологических фондов предприятий), систему экологических банков, особых банков для реализации крупных экологических проектов. Кроме этого, он должен отвечать за привлечение средств фондов экологического страхования, средств Мирового и Европейского банков и фондов организаций к финансированию природоохранных акций, самими предприятиями, использование собственных средств на восстановление и охрану природы, а также использование льготных экологических инвестиционных кредитов.

Если говорить о природоохранной политике, то здесь важно повысить значимость регионов в финансировании природоохранных мероприятий и акций, а также создание в них объектов экологической инфраструктуры, тем самым, повышая их инвестиционную привлекательность. Рыночные отношения поставили природоохранный комплекс России в условия, приведшие к кардинальному изменению управления инвестиционной деятельностью и дальнейшей переоценки системы охраны природы. В настоящее время формируется механизм природоохранных инвестиций и постоянно возрастает значимость регионов в экологическом инвестировании.

Нельзя не подчеркнуть, что в РФ система платежей за загрязнение окружающей среды имеет ряд недостатков. Прежде всего, стимулирующая функция платежей не работает вообще, ставки платежей сравнительно невысоки. Да и сам процесс платы за загрязнение окружающей среды устарел. Поэтому предприятия и организации ведут собственный учет сбросов и выбросов вредных и экологически опасных веществ, не проводится контроль за порядком предоставления данных о видах и количестве экологически опасных выбросов, осуществляемый предприятиями региона.

Кроме того, платежи за загрязнение окружающей среды - это затратные методы ограничения загрязнений, часть которых приходится на потребителей продукции. Производители, перенося затраченные в счет платежей средства на цену своей продукции, предприятия-оптовики окажутся в лучшем положении, чем те, которые не смогут это сделать.

Используя опыт западных стран, вместо платежей за загрязнение окружающей природной среды, можно использовать лицензирование выбросов экологически вредных веществ. На такой метод можно будет перевести систему государственного регулирования природопользования в систему рыночного управления.

И еще один немаловажный фактор в реализации программ финансирования курортного региона, который на рекреационной территории не используется в полной мере - это страхование, о значении и эффективности которого имеется немало научных разработок у Коломиец Л.Г.: «Доказана роль финансовой инфрасистемы субрегиона Кавказских Минеральных Вод в решении проблем обеспечения страховой защиты объектов рекреации, снижении инвестиционных рисков, что обусловлено снижением 
возможностей имеющегося курортно-оздоровительного потенциала, через освоение новых кредитно-инвестиционных продуктов, межотраслевое и межрегиональное перераспределение финансовых ресурсов, в том числе страховых фондов» [2, с. 9]. Страховые фонды, создаваемые за счет страховых платежей страхователей, могли бы полностью обеспечить выплату страхового возмещения пострадавшему при наступлении страхового случая. А страховые риски, подлежащие страхованию, весьма разнообразны - объекты могут быть не только материальные, но и моральные, например, страхование отдыхающих от плохой погоды, от неполучения эффекта курортного лечения и др.

Итак, можно подвести итоги проведенного исследования. Было выявлено недостаточное выполнение обязательств по финансированию госпрограмм развития курорта Кавказских Минеральных Вод.

Предложены пути создания негосударственных источников финансирования природоохранной деятельности на рекреационной территории (инновационные, страховые и экологические фонды, средства местных бюджетов, собственные средства предприятий, в том числе их экологических фондов, средства общественных организаций, меценатов, внутренние кредиты, кредиты, взятые за рубежом, гранты).

Акцентировано внимание на страховании, как действенном способе защиты имущественных интересов собственников, в том числе санаторно-курортного и туристского комплекса КМВ и СКФО в целом.

\section{Библиографический список}

1. Стратегия социально-экономического развития Северо-Кавказскогофедерального округа до 2025 года. Утверждена Распоряжением Правительства Российской Федерации от06 сентября 2010 года № 1485.Электронный доступ: pinfo@krskfo.ru

2. Коломиеи Л.Г. Автореферат диссертации на соискание ученой степени доктора экономических наук «Реализация экономических интересов в системе страховых отношений».- Москва, 2010.- Электронный доступ: new-disser.ru 